\title{
Arterial thrombosis and cancer: the neglected side of the coin of Trousseau syndrome
}

\author{
Valerio De Stefano
}

Fondazione Policlinico Universitario A. Gemelli IRCCS, Istituto di Ematologia, Università Cattolica, Roma, Italia

E-mail: valerio.destefano@unicatt.it

doi:10.3324/haematol.2018.197814

T

he clinical observation of the association between cancer and thrombosis was first reported in 1823 by Jean Baptiste Bouillaud when he was still a medical student. ${ }^{1}$ However, Armand Trousseau in 1865 was the first to study systematically clinical and autopsy findings and formulate the theory of the close and frequent association between cancer and increased risk of thrombosis. He re-examined the previous observations: "I have just reperused the memoir of Dr. Bouillaud, and have pleasure in stating that the work of my colleague is as complete as if it had been written yesterday." In his $95^{\text {th }}$ lecture on clinical medicine, delivered at the Hôtel Dieu in Paris, he noted: "I have long been struck with the frequency with which cancerous patients are affected with painful oedema in the superior or inferior extremities, whether one or other was the seat of cancer. [...] I have since that period had an opportunity of observing other cases of painful oedema, in which, at the autopsy, I found visceral cancer, but in which during life, there was no appreciable cancerous tumor; and in which there existed a cachexia referable neither to the tubercular diathesis, the puerperal state, nor chlorosis. I have thus been led to the conclusion, that when there is a cachectic state not attributable to the tuberculous diathesis or to the puerperal state, there is most probably a cancerous tumor in some organ. [...] So great, in my opinion, is the semiotic value of phlegmasia in the cancerous cachexia, that I regard this phlegmasia as a sign of the cancerous diathesis as certain as sanguinolent effusion into the serous cavities." ${ }^{2}$

The procoagulant mechanisms underlying cancer-associated thrombophilia are complex and multifactorial. However, the expression of tumor cell-associated clot promoting properties leads to the activation of the clotting cascade, with the generation of thrombin and fibrin, and the stimulation of platelets, leukocytes and endothelial cells, enhancing their cellular procoagulant features. ${ }^{3}$ A possible particular role of neutrophil extracellular traps

Table 1. Studies investigating the incidence of arterial thrombosis conducted in patient cohorts composed of different cancer groups.

\begin{tabular}{|c|c|c|c|c|c|c|c|c|c|c|}
\hline Reference & $\begin{array}{c}\text { Cancer } \\
\text { patients, } n\end{array}$ & $\begin{array}{l}\text { Time } \\
\text { frame }\end{array}$ & Design & $\begin{array}{l}\text { Inclusion } \\
\text { criteria }\end{array}$ & $\begin{array}{l}\text { Source of } \\
\text { information }\end{array}$ & $\begin{array}{l}\text { ATE, } \\
\text { n }(\%)\end{array}$ & $\begin{array}{l}\text { Risk vs. } \\
\text { controls }\end{array}$ & $\begin{array}{l}\text { AMI, } \\
\text { n (\%) }\end{array}$ & $\begin{array}{l}\text { IS, } \\
\text { n }(\%)\end{array}$ & $\begin{array}{l}\text { VIE, } \\
\text { n (\%) }\end{array}$ \\
\hline Khorana et al. ${ }^{10}$ & 66,106 & 1995-2002 & $\begin{array}{l}\text { Multicenter } \\
\text { retrospective } \\
\text { cohort }\end{array}$ & $\begin{array}{l}\text { Diagnosis of cancer, } \\
\text { hospitalization, } \\
\text { chemotherapy, } \\
\text { neutropenia }\end{array}$ & $\begin{array}{l}\text { Discharge } \\
\text { database }\end{array}$ & $\begin{array}{c}1135 \\
(1.72 \%)\end{array}$ & N/A & $\begin{array}{c}577 \\
(0.87 \%)\end{array}$ & $\begin{array}{c}422 \\
(0.64 \%)\end{array}$ & $\begin{array}{c}4255 \\
(6.44 \%)\end{array}$ \\
\hline Di Nisio et al. ${ }^{11}$ & 1934 & 2003-2009 & $\begin{array}{l}\text { Multicenter } \\
\text { retrospective } \\
\quad \text { cohort }\end{array}$ & $\begin{array}{l}\text { Diagnosis of cancer, } \\
\text { ambulatory follow up, } \\
\text { chemotherapy, } \\
\text { no history of ATE }\end{array}$ & $\begin{array}{l}\text { Medical } \\
\text { records }\end{array}$ & $\begin{array}{c}5 \\
(0.27 \%)\end{array}$ & N/A & $\begin{array}{c}4 \\
(0.20 \%)\end{array}$ & 0 & $\begin{array}{c}38 \\
(1.96 \%)\end{array}$ \\
\hline Zoller et al. ${ }^{12,13}$ & 820,491 & $1987-2008$ & $\begin{array}{c}\text { Nationwide } \\
\text { retrospective cohort }\end{array}$ & $\begin{array}{l}\text { Diagnosis of } \\
\text { cancer }\end{array}$ & $\begin{array}{l}\text { National } \\
\text { omputerized registry } \\
\text { (MigMeg2 database) } \\
\text { based on unique } \\
\text { person number }\end{array}$ & N/A & $\begin{array}{l}\text { At } 6 \text { months } \\
1.7 \text { (AMI) } \\
2.2 \text { (IS) }\end{array}$ & $\begin{array}{l}34,666 \\
(4.2 \%)\end{array}$ & $\begin{array}{l}31,524 \\
(3.8 \%)\end{array}$ & $\mathrm{N} / \mathrm{A}$ \\
\hline Navi et al. ${ }^{14}$ & 279,719 & 2002-2011 & $\begin{array}{l}\text { Retrospective } \\
\text { matched cohort }\end{array}$ & $\begin{array}{l}\text { Age }>65 \text { years, } \\
\text { primary breast, } \\
\text { lung, prostate, colorectal, } \\
\text { bladder, pancreatic, } \\
\text { gastric cancer or } \\
\text { non-Hodgkin lymphoma }\end{array}$ & $\begin{array}{l}\text { SEER-Medicare } \\
\text { dataset }\end{array}$ & $\begin{array}{l}\text { Cumulative } \\
\text { incidence } \\
\text { at } 1 \mathrm{yr}: 6.5 \% \\
\text { at } 2 \text { yrs:9.1\% }\end{array}$ & $\begin{array}{l}\text { At } 6 \text { months } \\
2.2 \text { (ATE) } \\
2.9 \text { (AMI) } \\
1.9 \text { (IS) }\end{array}$ & $\begin{array}{l}\text { Cumulative } \\
\text { Incidence } \\
\text { at } 1 \mathrm{yr}: 2.6 \% \\
\text { at } 2 \text { yrs:3.7\% }\end{array}$ & $\begin{array}{l}\text { Cumulative } \\
\text { Incidence } \\
\text { at } 1 \text { yr: } 4.3 \% \\
\text { at } 2 \text { yrs:5.8\% }\end{array}$ & $\begin{array}{ll}\mathrm{e} & \mathrm{N} / \mathrm{A} \\
\% & \\
\% & \end{array}$ \\
\hline Brenner $\mathrm{et} \mathrm{al.} .^{15}$ & 5717 & 2009-2014 & $\begin{array}{c}\text { Multicenter } \\
\text { prospective cohort }\end{array}$ & $\begin{array}{l}\text { Active cancer, } \\
\text { previous VTE }\end{array}$ & $\begin{array}{l}\text { RIETE } \\
\text { registry }\end{array}$ & $\begin{array}{c}63 \\
(1.10 \%)\end{array}$ & N/A & $\begin{array}{c}15 \\
(0.26 \%)\end{array}$ & $\begin{array}{c}42 \\
(0.73 \%)\end{array}$ & $\begin{array}{c}499 \\
(8.72 \%)\end{array}$ \\
\hline Grilz et $a l^{8}{ }^{8}$ & 1880 & 2003-2013 & $\begin{array}{l}\text { Monocenter } \\
\text { prospective } \\
\text { cohort }\end{array}$ & $\begin{array}{c}\text { Age }>18 \text { years, newly } \\
\text { diagnosed or relapsed } \\
\text { cancer, no indication } \\
\text { to long-term } \\
\text { anticoagulation }\end{array}$ & CATS dataset & $\begin{array}{c}48 \\
(2.55 \%) \\
\text { Cumulative } \\
\text { Incidence } \\
\text { at } 1 \text { yr: } 1.7 \% \\
\text { at } 2 \text { yrs:2.6\% }\end{array}$ & N/A & $\begin{array}{c}20 \\
(1.06 \%)\end{array}$ & $\begin{array}{c}16 \\
(0.85 \%)\end{array}$ & $\begin{array}{c}157 \\
(8.35 \%)\end{array}$ \\
\hline
\end{tabular}

n: number; yr/yrs: year(s); N/A: not available; AMI: acute myocardial infarction; ATE: arterial thromboembolic event; CATS:Vienna Cancer and Thrombosis Study; IS: ischemic stroke; RIETE: Registro Informatizado de Enfermedad TromboEmbolica; SEER: Surveillance Epidemiology and End Results-Medicare;VTE: venous thromboembolism. 


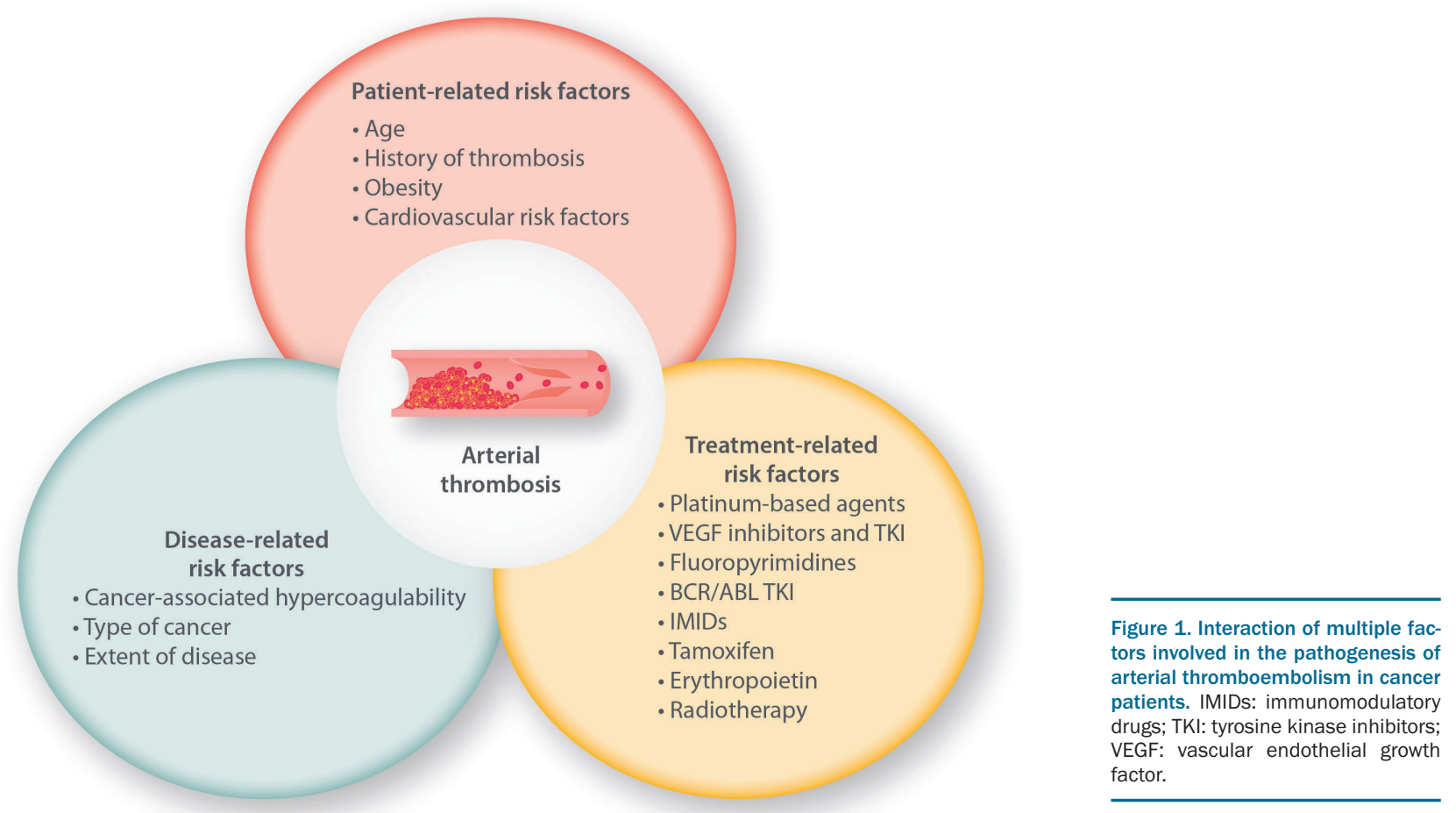

(NETs) in promoting cancer-associated arterial thrombosis has been reported in patients with ischemic stroke and cancer. $^{4}$

According to Trousseau's first observations, traditionally the association between thrombosis and malignancy has been focused on the occurrence of venous thromboembolism (VTE). Overall, cancer has been reported to account for $17-29 \%$ of all VTE cases; ${ }^{5}$ on the other hand, in the prospective Vienna Cancer and Thrombosis Study (CATS), $7.7 \%$ of the cancer patients developed VTE within one year after diagnosis or progression of the disease. ${ }^{6}$

The epidemiology of arterial thrombosis in cancer patients has received much less attention. Indeed, thrombosis in arteries has long been recognized in cancer patients. In this issue of the Journal, Grilz et al. report the up-dated results of the CATS study, aimed to investigate the incidence of arterial thromboembolism (ATE), the related risk factors, and the impact on mortality in a cohort of 1880 patients with active newly diagnosed or relapsed cancer. ${ }^{8}$

The global burden of arterial thrombosis in the general population for the two common artery acute diseases (i.e. acute myocardial infarction and ischemic stroke) has been estimated to be 139.3 and 114.3 per 100,000 people, accounting for an overall incidence rate of $0.25 \%$ of individuals. $^{9}$ In the CATS cohort, the frequency of ATE was $2.6 \%$ during a median prospective observation time of two years. In agreement with previous reports, the rate of VTE was $8.4 \% .^{8}$ It is difficult to compare this with earlier reports due to the considerable heterogeneity in the design, inclusion criteria, and source of information (Table 1). ${ }^{10-15}$ In the paper of Grilz et al., the multivariable analysis demonstrated among the types of cancer a significant association only with kidney cancer [Hazard Ratio
(HR) 1.6$]^{8}$ this association had already been reported in some cohorts ${ }^{12,13}$ but not in others. ${ }^{10}$ Lung cancer was found to be significantly associated with ATE in most reports; $;^{10,12-15}$ this was confirmed in the CATS cohort but only under univariable analysis. ${ }^{8}$ Cancer stage has been reported to be associated with the risk of ATE, ${ }^{12-15}$ but this increase in risk has not been found in the CATS cohort, ${ }^{8}$ in agreement with a report on hospitalized patients under chemotherapy. ${ }^{10}$

Grilz et al. addressed the role of cardiovascular risk factors in the CATS cohort as determinants of ATE in cancer; age, male sex, and smoking were independent risk factors for ATE. Moreover, history of cardiovascular disease, hypertension, and medical conditions needing treatment with lipid-lowering agents or antiplatelet agents were all associated with a 2.2-3.7-fold increase in risk of ATE. This was aligned with the findings obtained in the RIETE cohort of cancer patients with VTE, in which history of arterial thrombosis, hypertension, diabetes, and use of statins were over-represented in the patients with subsequent ATE compared with those without. ${ }^{15}$ The role of previous ATE as a predictor of a novel ATE is indirectly confirmed by the low rate of ATE in the study of Di Nisio et al., ${ }^{11}$ in which patients with a history of cardiovascular events were excluded. The median age of the patients recruited in the CATS cohort was 61 years, explaining the relatively lower rate of ATE with respect to the study based on the SEER-Medicare dataset, which collected data from patients over 65 years of age (Table 1). ${ }^{14}$

Notably, the presence of two or more cardiovascular risk factors (hypertension, diabetes, known arterial cardiovascular disease, and dyslipidemia) resulted in an as high as $5.6-12.5 \%$ higher risk of ATE at two years from diagnosis in comparison with patients with none or a sin- 
gle risk factor (cumulative incidence of ATE 1.4-2.7\% at 2 years) (Online Supplementary Appendix). ${ }^{8}$

The risk of cancer-related ATE has been reported to vary during the disease, being highest during the first 612 months after diagnosis and then declining. ${ }^{12-14}$ In the CATS cohort, the peak of ATE soon after diagnosis was modest and was then subsequently constant over the entire follow-up period, in contrast to VTE, which peaked during the first six months after diagnosis. ${ }^{8}$ This distribution could be due to different compositions of the patient cohorts as regards type of cancer, as well as the presence of cardiovascular risk factors. The time distribution of cancer-related ATE has been reported to vary according to the nature of the disease. Patients with colorectal cancer, bladder cancer, and non-Hodgkin lymphoma showed an increased risk of myocardial infarction but not of ischemic stroke beyond one year. ${ }^{14}$ On the other hand, attenuation of the incidence rate of ATE over time or persistence up to ten years from the diagnosis has been variously described according to different cancer diagnoses. ${ }^{12,13}$

However, the constant rate of ATE over time could be explained by the role of cardiovascular risk factors as a persistent trigger independently of the course of the cancer. It should be pointed out that, in the CATS cohort, cardiovascular risk factors that are significantly associated with ATE, such as hypertension or known arterial cardiovascular disease, are present in $37.5 \%$ and $8.5 \%$ of the cohort, respectively. Moreover, 303 patients $(16.1 \%$ of the entire cohort) were at higher risk (i.e. presence of 2 or more cardiovascular risk factors) (Online Supplementary Appendix). ${ }^{8}$

In cancer patients, the development of ATE has been reported to be associated with a 4-5-fold increased hazard for death. ${ }^{10,14}$ This was substantially confirmed in the CATS cohort, where the occurrence of ATE was associated with a 3.2-fold increased risk of death. ${ }^{8}$

The major limitation of the study of Grilz et al., ${ }^{8}$ as of the other studies, is the lack of information about cancer treatment (chemotherapy or radiotherapy). Many therapeutic agents are associated with a significant risk of ATE or VTE, as recently reviewed (Figure 1). ${ }^{16,17}$ Therefore the drugs used for the active treatment of cancer are essential co-variates in the estimate of the hazard risk of the cancer-related thrombosis. Moreover, antithrombotic prophylaxis administered during active therapy should be taken into account. In the RIETE cohort of cancer patients who have had a VTE event, $86 \%$ of the subsequent ATE events occurred during heparin treatment and only $6.3 \%$ during antiplatelet treatment. ${ }^{15}$

In conclusion, ATE is fully recognized as a less frequent but key part of Trousseau syndrome, complicating the course of cancer and having a significant impact on the prognosis. As has been well established for VTE, ATE can be the first signal of an otherwise occult malignancy and can precede the overt diagnosis, ${ }^{4,18}$ such that it should arouse suspicion of a potential cancer, especially in those patients without cardiovascular risk factors.

The awareness that cancer itself could be an additional risk factor for ATE, and that cancer therapy can also cause short-term and long-term cardiovascular complications, makes it mandatory to identify high-risk patients, to modify the pre-existent cardiovascular risk factors, and to adopt effective antithrombotic prophylaxis. ${ }^{19,20}$ Early diagnosis and timely intervention in response to these issues can significantly improve the management of cancer patients and lead to a better outcome, especially for those who are elderly or who have cardiovascular risk factors, and those undergoing therapies with cardiovascular toxicity.

\section{References}

1. Bouillaud JB. De l'obliteration des veines et de son influence sur la formation des hydropisies partielles: consideration sur la hydropisies passive et general. Arch Gen Med. 1823;1(2):188-204.

2. Trousseau A. Lecture XCV. Phlegmasia alba dolens. In: Lectures on Clinical Medicine, delivered at the Hôtel-Dieu, Paris, translated from the Third Edition of 1868 by Sir J. R. Cormack. London: The New Sydenham Society; 1872. vol. 5, p. 281-332.

3. Ay C, Pabinger I, Cohen AT. Cancer-associated venous thromboembolism: burden, mechanisms, and management. Thromb Haemost. 2017;117(2):219-230.

4. Thålin C, Demers M, Blomgren B, et al. NETosis promotes cancer-associated arterial microthrombosis presenting as ischemic stroke with troponin elevation. Thromb Res. 2016;139:56-64.

5. Timp JF, Braekkan SK, Versteeg HH, Cannegieter SC. Epidemiology of cancer-associated venous thrombosis. Blood. 2013;122(10):1712-1723.

6. Ay C, Dunkler D, Marosi C, et al. Prediction of venous thromboembolism in cancer patients. Blood. 2010;116(24):5377-5382.

7. Sack GH Jr, Levin J, Bell WR. Trousseau's syndrome and other manifestations of chronic disseminated coagulopathy in patients with neoplasms: clinical, pathophysiologic, and therapeutic features. Medicine (Baltimore). 1977;56(1):1-37.

8. Grilz E, Königsbrügge $O$, Posch F, et al. Frequency, risk factors, and impact on mortality of arterial thromboembolism in patients with cancer. Haematologica. 2018 May 24. [Epub ahead of print]

9. Wendelboe AM, Raskob GE. Global Burden of Thrombosis: epidemiologic aspects. Circ Res. 2016;118(9):1340-1347

10. Khorana AA, Francis CW, Culakova E, Fisher RI, Kuderer NM, Lyman GH. Thromboembolism in hospitalized neutropenic cancer patients. J Clin Oncol. 2006;24(3):484-490.

11. Di Nisio M, Ferrante N, Feragalli B, et al. Arterial thrombosis in ambulatory cancer patients treated with chemotherapy. Thromb Res. 2011;127(4):382-383.

12. Zöller B, Ji J, Sundquist J, Sundquist K. Risk of coronary heart disease in patients with cancer: a nationwide follow-up study from Sweden. Eur J Cancer. 2012;48(1):121-128.

13. Zöller B, Ji J, Sundquist J, Sundquist K. Risk of haemorrhagic and ischaemic stroke in patients with cancer: a nationwide follow-up study from Sweden. Eur J Cancer. 2012;48(12):1875-1883.

14. Navi BB, Reiner AS, Kamel H, et al. Risk of Arterial Thromboembolism in Patients With Cancer. J Am Coll Cardiol. 2017;70(8):926-938.

15. Brenner B, Bikdeli B, Tzoran I, et al; RIETE Investigators. Arterial ischemic events are a major complication in cancer patients with venous thromboembolism. Am J Med. 2018 May 25. [Epub ahead of print]

16. Aronson D, Brenner B. Arterial thrombosis and cancer. Thromb Res. 2018;164 Suppl 1:S23-S28.

17. Tuzovic M, Herrmann J, Iliescu C, Marmagkiolis K, Ziaeian B, Yang EH. Arterial thrombosis in patients with cancer. Curr Treat Options Cardiovasc Med. 2018;20(5):40.

18. Sundbøll J, Veres K, Horváth-Puhó E, Adelborg K, Sørensen HT. Risk and prognosis of cancer after lower limb arterial thrombosis. Circulation. 2018 Mar 14. [Epub ahead of print]

19. Chang HM, Moudgil R, Scarabelli T, Okwuosa TM, Yeh ETH. Cardiovascular complications of cancer therapy: best practices in diagnosis, prevention, and management: part 1. J Am Coll Cardiol. 2017;70(20):2536-2551.

20. Chang HM, Okwuosa TM, Scarabelli T, Moudgil R, Yeh ETH Cardiovascular complications of cancer therapy: best practices in diagnosis, prevention, and management: part 2. J Am Coll Cardiol. 2017;70(20):2552-2565. 